\title{
EFL TEACHERS' EXPERIENCES DURING THE PANDEMIC: STORIES FROM RURAL AREA IN TUNGKAL ILIR DISTRICT
}

\author{
Pahrozi Ahmad*, Anita Triastuti \\ Yogyakarta State University, Indonesia \\ (pahrozi0008pasca.2020@student.uny.ac.id)
}

Received: 07 September 2021; Revised: $23^{\text {th }}$ November 2021; Accepted: 27 December 2021

\begin{abstract}
This article explores the implementation of online learning by English teachers in the age of the coronavirus pandemic in the Tungkal Ilir district, West Tanjung Jabung Regency. This article examines two research questions: (1) How do EFL teachers describe their practices and perceptions of online learning during the pandemic, and (2) What challenges EFL teachers face while implementing online learning during the pandemic. In this small-scale qualitative study, three English teachers took part. Semi-structured interviews were used to gather information. The result revealed that teachers in remote areas used social media and digital platforms to carry out their online teaching. On the other hand, these teachers had some issues incorporating online learning. The problems can be divided into two categories: (a) unfamiliarity with the platforms and (b) inability to respond to students quickly. In addition, some suggestions are also given for further researchers to conduct a similar study.
\end{abstract}

Key Words: COVID-19; EFL teachers' experiences; rural areas

\begin{abstract}
ABSTRAK
Artikel ini membahas tentang implementasi pembelajaran online oleh guru bahasa Inggris di era pandemi virus corona di kecamatan Tungkal Ilir, Kabupaten Tanjung Jabung Barat. Artikel ini membahas dua pertanyaan penelitian: (1) Bagaimana guru EFL menggambarkan praktik dan persepsi mereka tentang pembelajaran online selama pandemi, dan (2) Apa tantangan yang dihadapi guru EFL saat menerapkan pembelajaran online selama pandemi. Tiga guru Bahasa Inggris diambil sebagai responden dalam studi kualitatif skala kecil ini. Wawancara semi terstruktur digunakan untuk mengumpulkan informasi. Hasil penelitian menunjukkan bahwa guru di daerah terpencil telah menggunakan media sosial dan platform digital untuk melaksanakan pengajaran online mereka. Disisi lain, guru memiliki beberapa masalah dalam penerapan pembelajaran online. Masalah dapat dibagi menjadi dua kategori: (a) ketidaktahuan dengan platform dan (b) ketidakmampuan untuk merespon siswa dengan cepat. Selain itu, beberapa saran juga diberikan bagi peneliti selanjutnya untuk melakukan penelitian serupa.
\end{abstract}

Kata Kunci: COVID-19; pengalaman guru EFL; daerah pedesaan

How to Cite: Ahmad, P., \& Triastuti, A. (2021). EFL Teachers' Experiences During the Pandemic: Stories From Rural Area in Tungkal Ilir District. IJEE (Indonesian Journal of English Education), 8(2), 297-308. doi:10.15408/ijee.v8i2.22409

\footnotetext{
* Corresponding author
}

IJEE (Indonesian Journal of English Education), 8(2), 2021, 297-308

P-ISSN: 2356-1777, E-ISSN: 2443-0390 | DOI: http://doi.org/10.15408/ijee.v8i2.22409

This is an open access article under CC-BY-SA license (https://creativecommons.org/licenses/by-sa/4.0/) 


\section{INTRODUCTION}

The current global pandemic resulting from the Coronavirus disease 2019 (Covid-19) outbreak has significantly altered how people behave in their daily lives (Nugroho et al., 2021). All countries worldwide that have been affected by this contagious disease require their society to do social and physical distancing to avoid infection (Reluga, 2010). In reaction to this, the Indonesian Minister of Education and Culture has urged schools to do online learning for COVID-19 affected districts (Mendikbud, 2020b). As a result of COVID-19's rising dissemination, he has also ordered all education units to implement online learning by 24 March 2020 (Mendikbud, 2020a). In order to comply with these policies, students must learn online, and teachers must work from home. Thus, it completely substitutes face-to-face classroom learning with online learning.

The term 'online learning' refers to the educational procedure through electronic devices such as computers, tablets, and smartphones, thus requiring a connection to the Internet. Indeed, it is a type of distance education that allows students to acquire education from anywhere they are. To communicate with others, students and teachers can use applications such as Skype and
WhatsApp or use other methods such as email and videos or podcasts (Gonzalez \& St. Louis, 2018). However, distance education covers challenges such as geographical distance and a variety of other factors that hinder students from attending classes in person (Hrastinski, 2008; Kara, 2020; Singh \& Thurman, 2019).

As mentioned earlier, the COVID19 pandemic has caused the educational system to shift from formal classroom contact to casual digital learning. The abrupt shifting has several repercussions. First, it astounds teachers, students, school administrators, and authorities because the global pandemic was not predicted previously (Amin \& Sundari, 2020). Second, teachers and students must adapt to emergency online teaching and learning (Abdulkareem \& Eidan, 2020). Lastly, for both teachers and students, the transition from face-to-face classroom engagement to online teaching and learning includes some benefits, challenges, and drawbacks (Ivone et al., 2020; Satar \& Akcan, 2018).

Research has shown that online learning has some advantages for both teachers and students that have been thoroughly documented, such as in online teaching pedagogy (J. A. Cohen, 2020), online teaching strategies (Inayati et al., 2021), and instruction 
methods and curriculum design (Kostoulas-Makrakis, 2016). In addition, Halim and Hashim (2019) found that online learning can improve classroom engagement, communication skills, and self-confidence. Furthermore, Pazilah et al. (2019) mentioned that entertaining and engaging online learning activities could boost students' motivation. Teachers can use authentic learning materials through videos, television clips, and other helpful multimedia sources (e.g., YouTube, Wikimedia, Wikipedia, and Spotify) to make online learning fun.

In line with this, digital platforms such as applications, learning management systems, and social networking sites can be utilized in teaching and learning activities during the pandemic. For example, to improve the efficacy of teaching and learning, today's language learning has extensively integrated numerous digital technologies, social media, and virtual environments (Lam et al., 2018; Nugroho \& Mutiaraningrum, 2020). The result shows that it significantly impacts language learners' development (Chun et al., 2016; Hembrough \& Jordan, 2020; Lam et al., 2018)

Although there are numerous benefits to online learning, there are also issues to consider when establishing online classes or learning activities. For example, students may become sidetracked by other online content due to digital activities, reducing their involvement in the class lesson or activity (Omar et al., 2012). Furthermore, there is the risk of encountering technical issues, such as audio and video abnormalities (Halim \& Hashim, 2019). Despite online learning issues, teachers and administrators will need to devise inventive solutions based on best practices to ensure that academic learning objectives and goals are accomplished in the face of a rapidly spreading pandemic around the world.

The problem mentioned above indicates a need to understand the various perceptions of online learning among teachers in rural areas during the pandemic. Therefore, this study will explore EFL teachers' perceptions of online learning in rural areas in the Tungkal Ilir district during Coronavirus pandemic circumstances. With this aim, this paper addresses the following research questions: 1) How do EFL teachers describe their online learning practices in rural areas during the pandemic?; 2) What are the challenges that EFL teachers face while implementing online learning in rural areas during the pandemic? 


\section{METHOD}

\section{Research Design}

An interpretive paradigm was used to perform this qualitative study. A concern for the individual characterizes this paradigm. In the interpretive paradigm, the primary goal is to comprehend the subjective world of human experience (L. Cohen et al., 2017). Therefore, the natural object of this research is basically in the form of qualitative entities such as social phenomena, perceptions, and problems in online learning.

\section{Research Site and Participants}

Three on-duty English teachers at a Junior High School in Tungkal Ilir district were chosen to be the research participants. The participants must have met the following criteria: online teaching English during the pandemic and teaching in rural schools (Desa Teluk Sialang and Desa Tungkal 1). Then, for the sake of confidentiality of participants, they are referred to as initials instead of names.

\section{Data Collection and Analysis}

Data were collected through indepth semi-structured interviews, in which interviewees (participants) will be asked a series of questions about their perceptions of online teaching during the pandemic. According to
Newby (2014) and Mears (2012), indepth semi-structured interviews help gather thorough information on one's attitudes and habits and investigate new subjects in greater depth. It means that the researcher can explore more about what they know about a topic, what they have encountered, how they feel about specific issues, and how they view the specific issues. The semistructured interview lasted for about 60 minutes for each participant and was conducted through a telephone call.

While conducting a semistructured interview, a set of questions is prepared as the basis for the initial query. It serves as a guide to ensure that the interview does not stray from the topic at hand. In other words, the interviewer has guidance in hands, but it is still possible to extend the interview when a new issue appears. Before starting the interview, the participant was notified and permitted to record the conversation. The interview recordings were transcribed, and the transcription then is analyzed by referring to the procedures introduced by Flick (2002), namely open coding, axial coding, and selective coding.

\section{FINDINGS AND DISCUSSION}

Since there are two research questions proposed in this study, the 
findings will be divided into two sections: 1) Teachers' perceptions of online learning and 2) The challenges of online teaching.

\section{Teachers' Perceptions of Online Learning}

One of the questions asked during the interview was, "How do you describe online learning in teaching English in the classroom?" This question was specifically addressed to determine the teachers' basic comprehension of online teaching. It is believed that teachers with a good understanding and favorable opinion of online learning are thought to impact the success and efficacy of their classes substantially. In addition, their knowledge will also help them integrate online learning during the pandemic.

There was much agreement among teachers when it came to answering the question. They claimed that online learning was poorly implemented.

"Theoretically, online learning is, uhm, a learning system where students and teachers are in a separate place. Usually, it can be done synchronously or asynchronously". (Ms. MPS/5)

"Online learning needs an internet connection, so, I think, the implementation of online learning in our place is not well implemented.
There are so many challenges we have encountered". (Ms. NU/7)

"Online learning can be conducted if teachers and students have a strong internet connection. However, the most important thing is that the students must have supported technology, such as smartphones. In fact, some students do not have it". (Ms. MF/10)

The teachers' description of online learning and how they carried it out indicate that it is somehow problematic. The results of teachers implementing online learning are also shown in some other schools in Indonesia through some studies by Atmojo and Nugroho (2020) and Moser et al. (2021). Their studies reported that the teachers shared a similar perception that online learning is somehow problematic and needs a strong internet connection and adequate supporting technology.

Two months after the Covid-19 outbreak began, Giovannella et al. (2020) undertook a study in the Italian school to reveal the teachers' understanding and experience of online learning. It was found that teachers were more likely to have a good understanding of implementing technologies while teaching. It means that teachers' understanding of the technology used is needed to prepare for future teaching activities. To this 
end, (Federkeil et al., 2020) also advises that teachers improve their digital skills. Since online teaching methods are becoming increasingly popular, schools should provide the required hardware and software, such as computers needed by the teachers.

The semi-structured interviews also indicated the teaching platform used during the social distancing era. In general, teaching platforms can be classified into three types: they are as follows: (1) chat and message; (2) video conference; (3) YouTube. This result aligns with Atmojo and Nugroho (2020) and Correia et al. (2020) that the most utilized platform in teaching during the social distancing era are WhatsApp, ZOOM, Google Meeting, and YouTube.

Teaching through WhatsApp, according to Tragant et al. (2020), can promote interaction between teacher and student, as well as among students. Although student participation dwindled with time, teachers said that students wrote most WhatsApp messages as part of teacher-initiated projects. Thus, the teacher-initiated projects could help them practice their language skills and engage in authentic communication.

In this case, all participants agree that using WhatsApp in teaching during the pandemic is simple and easy to operate.
"I use WhatsApp to share materials, YouTube links, give information about assignments, and provide questions and answer sessions." (Ms. NU/15)

"I sometimes utilize Google Meeting to explain materials, discuss with students, and provide question and answer sessions. At other times, I also use ZOOM. But, most of the time, I use WhatsApp in teaching". (Ms. $\mathrm{MF} / 18)$

"I attach YouTube video links in WAG to provide my students with visual materials." (Ms. NU/22)

\section{The Challenges of Online Teaching During the Pandemic}

Although online teaching activities could be conducted using several digital platforms, the participants' responses showed that they encountered several challenges. First, some participants confessed that they had not been familiar with online learning platforms at the beginning of online teaching administration. Second, for teachers, particularly in rural places, performing online teaching was a novel experience because they were used to face-to-face classroom interactions prior to the global epidemic. As a result, they had to quickly adjust to the current state of online teaching and learning. 
"At the beginning, the only option that comes to my mind is to run my online classes through WhatsApp because I am unfamiliar with other media. However, after discussing and practicing with my colleagues, I try to use other media such as video Zoom." (Ms. MPS/36)

"Yes... in the beginning, I hesitate how to carry out my online teaching activities with the students because I rarely use online learning tools." (Ms. MF/42)

Other research supports this finding, indicating that most teachers only have a rudimentary understanding of online learning and digital platforms (Adedoyin \& Soykan, 2020; Dhawan, 2020). Moreover, most teachers, especially those in rural regions, are used to having face-to-face classroom interactions rather than online learning through digital platforms, which could explain the unfamiliarity (Putri et al., 2020).

Second, participants indicated that they could not provide direct feedback and comments during the online teaching exercises. The incapacity could be attributed to a lack of digital platforms and limited internet connectivity. Although using a video conference such as Zoom, the participants noted that providing direct feedback and responses to the students' works or inquiries was challenging as in face-to-face teaching. In addition, poor internet connection possessed by both teachers and students overwhelmed the situation during the Covid-19 pandemic.

"I face problem in giving feedback to my students during the online teaching, especially when the teaching and learning are using online chatting like WhatsApp or Google classroom." (Ms. NU/49)

"One of my challenges in online teaching is being unable to respond quickly to my students' work and projects. In addition, I will have to deal with the complexities of teaching online with digital devices, which will take extra time. As a result, I rarely respond to the work of my students. Another challenge is the internet connection. When the electricity is off, there will be no internet connection. (Ms. MPS/53)

"I cannot give quick feedback or responses to my students' queries or remarks during online teaching due to a lack of internet access. Also, it seems that the students are not particularly motivated to participate in online learning. So, maybe, I have to design more interesting online teaching activities, although it is tough." (Ms. MF/45) 
This finding depicts that inability to provide quick responses and lack of students' engagement become the other challenges encountered by the teachers. These results agree with Friedman (2020) and Toquero (2020) that English teachers must deal with the complexity of online teaching, mainly teaching feedback and passive involvement of their students in online learning activities.

Furthermore, the participants also provided insights and suggestions to overcome the challenges both teachers and students encountered during the emergency of online teaching.

"The problem could be solved by involving teachers in certain training, workshops, or seminars addressing how to conduct efficient online learning so that they are familiar with the various online learning tools." (Ms. MPS/59)

"..... I think by joining some workshops or training, teachers can know how to use and design interactive online teaching". (Ms. $N U / 61)$

The most common recommendation for teachers is to participate in training and development programs to increase their abilities and understanding of digital learning platforms. Lailiyah and Cahyono (2017) mentioned that extensive involvement in such activities enables teachers to enhance their online learning capacity and equips them to design representative teaching activities. This result is consistent with the findings of Nugroho et al. (2021) and Sithole et al. (2019), who found that involving teachers in training and development programs is an excellent strategy to improve their professional competence.

\section{CONCLUSIONS AND SUGGESTION}

The present study examined the EFL teachers' experiences concerning how they carried out online teaching practices and their challenges in teaching in the age of Covid-19 pandemic. This study leads to several compelling results: 1) A variety of applications and platforms such as social media (e.g., WhatsApp, YouTube) and digital platforms (e.g., ZOOM, Google Meet) are employed to carry out online learning. However, many issues emerge from the students and the teachers. As a result of the lack of preparation and planning, online learning does not function efficiently; 2) The findings reveal the challenges of implementing online learning at a rural school in Tungkal Ilir district. For example, a lack of expertise with digital learning platforms and the inability to respond quickly to students, and a lack of technological infrastructure. These challenges demonstrate the importance 
of taking these findings into account and taking action by addressing the issues, particularly in terms of familiarizing and developing the technological field in all educational settings to meet desired learning outcomes.

Nonetheless, some limitations should be considered when evaluating this study. First, only three EFL teachers from remote Tanjung Jabung Barat Regency can participate in this study. Therefore, future studies in similar areas should be conducted with many participants and perform various data instruments (e.g., observation and survey) to depict more detailed data. Second, future studies should examine additional data sources such as observation and field notes to elicit the most reliable data and accurately reflect the current inquiry's intricacies to enhance the data and prevent subjective viewpoints.

\section{REFERENCES}

Abdulkareem, T. A., \& Eidan, S. M. (2020). Online learning for higher education continuity (during COVID-19 Pandemic): The challenges, advantages, disadvantages and how to overcome: A literature review. International Journal of Youth Economy, 4(2), 125-131. https:/ /doi.org/10.18576/ijye/04 0206

Adedoyin, O. B., \& Soykan, E. (2020). Covid-19 pandemic and online learning: the challenges and opportunities. In Interactive Learning Environments. https://doi.org/10.1080/1049482 0.2020 .1813180

Amin, F. M., \& Sundari, H. (2020). Efl students' preferences on digital platforms during emergency remote teaching: Video conference, LMS, or messenger application? Studies in English Language and Education, 7(2). https://doi.org/10.24815/ siele.v7 i2.16929

Atmojo, A. E. P., \& Nugroho, A. (2020). EFL Classes Must Go Online! Teaching Activities and Challenges during COVID-19 Pandemic in Indonesia. Register Journal, 13(1), 49-76. https://doi.org/10.18326/rgt.v13 i1.49-76

Chun, D., Smith, B., \& Kern, R. (2016). Technology in Language Use, Language Teaching, and Language Learning. Modern Language Journal, 100. https://doi.org/10.1111/modl.12 302

Cohen, J. A. (2020). A fit for purpose pedagogy: online learning designing and teaching. Development and Learning in Organizations, 35(4). 
https://doi.org/10.1108/DLO08-2020-0174

Cohen, L., Lawrence, M., \& Morrison, K. (2017). Research Methods in Education. Eighth Edition. In Research Methods in Education.

Correia, A. P., Liu, C., \& Xu, F. (2020). Evaluating videoconferencing systems for the quality of the educational experience. Distance Education, 41(4). https://doi.org/10.1080/0158791 9.2020.1821607

Dhawan, S. (2020). Online Learning: A Panacea in the Time of COVID-19 Crisis. Journal of Educational Technology Systems, 49(1). https://doi.org/10.1177/0047239 520934018

Federkeil, L., Heinschke, F., Jungmann, T., \& Klapproth, F. (2020). Teachers experiences of stress and their coping strategies during COVID - 19 induced distance teaching. Journal of Pedagogical Research, $4(4)$. https://doi.org/10.33902/jpr.202 0062805

Flick, U. (2002). Qualitative research State of the art. In Social Science Information (Vol. 41, Issue 1). https://doi.org/10.1177/0539018 402041001001

Giovannella, C., Passarelli, M., \& Persico, D. (2020). The Effects of the Covid-19 Pandemic on Italian Learning Ecosystems: the School Teachers' Perspective at the steady state. Interaction Design and Architecture(S), 45.

Halim, M. S. A. A., \& Hashim, H. (2019). Integrating web 2.0 technology in ESL classroom: A review on the benefits and barriers. Journal of Counseling and Educational Technology, 2(1). https://doi.org/10.32698/0381

Hembrough, T., \& Jordan, J. (2020). Creating a digital writing classroom: A mixed methods study about a first-year composition tablet initiative. International Journal of Instruction, 13(2).

https://doi.org/10.29333/iji.2020. $13239 a$

Hrastinski, S. (2008). What is online learner participation? A literature review. Computers and Education, 51(4).

https://doi.org/10.1016/j.compe du.2008.05.005

Inayati, N., Rachmadhani, R. A., \& Utami, B. N. (2021). Student's strategies in online autonomous English language learning. JEES (Journal of English Educators Society), 6(1). https://doi.org/10.21070/jees.v6i 1.1035

Ivone, F. M., Jacobs, G. M., \& Renandya, W. A. (2020). Far apart, yet close together: Cooperative learning in online education. Studies in English Language and Education, $7(2)$. 
https://doi.org/10.24815/siele.v7 i2. 17285

Kara, M. (2020). Distance education: a systems view of online learning: by Michael G. Moore and Greg Kearsley, Belmont, CA, Wadsworth Cengage Learning, 2012, 361 pp., £92.99 (paperback), ISBN: 978-1-111-52099-1. Educational Review, 72(6). https://doi.org/10.1080/0013191 1.2020.1766204

Kostoulas-Makrakis, N. (2016). Instructional Design and Curriculum Perspectives Applied in Online Teaching and Learning.

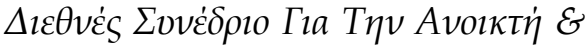

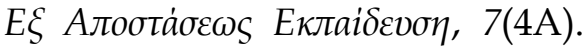
https://doi.org/10.12681/icodl.7 12

Lailiyah, M., \& Cahyono, B. Y. (2017). Indonesian EFL Teachers' SelfEfficacy towards Technology Integration (SETI) and Their Use of Technology in EFL Teaching. Studies in English Language Teaching, 5(2). https://doi.org/10.22158/selt.v5 n2p344

Lam, Y. W., Hew, K. F., \& Chiu, K. F. (2018). Improving argumentative writing: Effects of a blended learning approach and gamification. Language Learning and Technology, 22(1).

Mears, C. L. (2012). In-depth interviews. Research methods and methodologies in education, 19, 170-176.
Moser, K. M., Wei, T., \& Brenner, D. (2021). Remote teaching during COVID-19: Implications from a national survey of language educators. System, 97. https://doi.org/10.1016/j.system .2020 .102431

Newby, P. (2014). Research methods for education. Routledge.

Nugroho, A., \& Mutiaraningrum, I. (2020). EFL teachers beliefs and practices about digital learning of English. EduLite: Journal of English Education, Literature and Culture, $5(2)$.

https://doi.org/10.30659/e.5.2.30 4-321

Omar, H., Embi, M. A., \& Md Yunus, M. (2012). ESL learners' interaction in an online discussion via Facebook. Asian Social Science, $8(11)$.

https://doi.org/10.5539/ass.v8n1 $1 \mathrm{p} 67$

Pazilah, F. N. P., Hashim, H., \& Yunus, M. M. (2019). Using Technology in ESL Classroom: Highlights and Challenges. Creative Education, 10(12).

https://doi.org/10.4236/ce.2019. 1012244

Putri, R. S., Purwanto, A., Pramono, R., Asbari, M., Wijayanti, L. M., \& Hyun, C. C. (2020). Impact of the COVID-19 pandemic on online home learning: An explorative study of primary schools in Indonesia. International Journal of 
Advanced Science and Technology, 29(5).

Reluga, T. C. (2010). Game theory of social distancing in response to an epidemic. PLoS Computational Biology, $6(5)$. https://doi.org/10.1371/journal. pcbi.1000793

Satar, H. M., \& Akcan, S. (2018). Preservice EFL teachers' online participation, interaction, and social presence. Language Learning and Technology, 22(1).

Singh, V., \& Thurman, A. (2019). How Many Ways Can We Define Online Learning? A Systematic Literature Review of Definitions of Online Learning (1988-2018). American Journal of Distance Education, 33(4). https://doi.org/10.1080/0892364 7.2019.1663082
Toquero, C. M. (2020). Challenges and Opportunities for Higher Education amid the COVID-19 Pandemic: The Philippine Context. Pedagogical Research, 5(4). https://doi.org/10.29333/pr/794 7

Tragant, E., Pinyana, À., Mackay, J., \& Andria, M. (2020). Extending language learning beyond the EFL classroom through WhatsApp. Computer Assisted Language Learning. https://doi.org/10.1080/0958822 1.2020 .1854310 